\title{
The Significance of Pregnancy-associated Plasma Protein a Serum Concentration in Clear Cell Renal Cell Carcinoma
}

\author{
MARCELA CECHOVA ${ }^{1}$, MATUS CHOCHOLATY ${ }^{1}$, TOMAS ZIMA ${ }^{2}$, \\ MAREK BABJUK ${ }^{1}$ and MARTA KALOUSOVA ${ }^{2}$ \\ ${ }^{1}$ Department of Urology, University Hospital Motol, 2nd Faculty of Medicine, \\ Charles University, Prague, Czech Republic; \\ ${ }^{2}$ Institute of Medical Biochemistry and Laboratory Diagnostics, \\ General University Hospital and 1st Faculty of Medicine, Charles University, Prague, Czech Republic
}

\begin{abstract}
Background/Aim: Proteinase pregnancyassociated plasma protein A (PAPP-A) modulates the cell growth and carcinogenesis process. Its role in clear cell renal cell carcinoma (ccRCC) remains unclear. This study aimed to evaluate the significance of PAPP-A serum concentration in diagnosis, follow-up and prognosis of ccRCC patients. Materials and Methods: In a prospective study including 121 patients who underwent radical or partial nephrectomy for ccRCC [localized ccRCC without relapse $(n=80)$, localized $c c R C C$ with later relapse $(n=26)$, primary metastatic cancer (n=15)] PAPP-A serum concentration was assessed preoperatively and in certain subgroups also postoperatively. Results: PAPP-A serum concentration showed no statistically significant difference between ccRCC and controls and among ccRCC subgroups, respectively. Disease stage and Fuhrman's grade were not shown to affect PAPP-A concentration. The dynamics of postoperative PAPP-A concentrations did not reveal any significance and PAPP-A was not a prognostic factor for cancer related or overall survival. Conclusion: PAPP-A serum concentration does not seem to be a useful biomarker in ccRCC.
\end{abstract}

Renal cell carcinoma (RCC) accounts for 2-3\% of all adult malignancies presenting the highest incidence in the Western world (1). Incidence of RCC has been continuously increasing over the last years. Clear cell RCC (ccRCC) represents the most prevalent histopathological subtype,

Correspondence to: Prof. Marta Kalousová, MD, Ph.D., Institute of Medical Biochemistry and Laboratory Diagnostics, General University Hospital and 1st Faculty of Medicine, Charles University, Prague, 12808 Prague 2, U Nemocnice 2, Czech Republic. Tel: +420 224964212, e-mail: marta.kalousova@lf1.cuni.cz

Key Words: Pregnancy-associated plasma protein A, PAPP-A, clear cell renal cell carcinoma, diagnosis, prognosis. which is diagnosed in more than $80 \%$ of patients. The exact process of the formation and progression of ccRCC in not known. There are no recommended genetic or biochemical markers for diagnosis and prediction of relapse before surgical removal of the tumour or during follow-up.

Despite advances in diagnosis, especially in imaging techniques and higher rates of incidentally diagnosed tumours with imaging for unrelated complaints, still, in up to $30 \%$ of patient's, distant metastases are present at the time of initial diagnosis $(2,3)$. Furthermore, recurrence occurs in 20-30\% patients with an initially localized disease during the follow-up (4). RCC is potentially curative with surgery and it is generally resistant to chemotherapy and radiotherapy. Despite progress in targeted therapy, prognosis of metastatic RCC remains poor with median survival less than one year (3). Therefore, detection of a biomarker suitable for early diagnosis and, even more, for accurate determination of the risk of relapse after partial or radical nephrectomy is of great importance.

Pregnancy-associated plasma protein A (PAPP-A), also referred to as pappalysine- 1 is a proteolytic enzyme that belongs to the zinc metalloproteinase superfamily. PAPP-A increases bioavailability of insulin like growth factor 1 (IGF1) for receptor activation via proteolysis of inhibitory IGF binding proteins (IGFBPs), in particular IGFBP-4. Targeting IGF-1 receptor (IGF-1R) IGF-1 affects proteosynthesis (5). PAPP-A is expressed predominantly during pregnancy in placental syncythiotrophoblast and is required for normal foetal development and growth. Routinely, measurement of serum concentration of PAPP-A applies as a screening method for Down syndrome in the first trimester of gestation.

However, despite during pregnancy, PAPP-A is also expressed by multiple tissues and has an important role in processes like wound healing, vascular repair or bone remodelling. The involvement of the proteolytic effect of PAPP-A in the process of carcinogenesis is highly suggested 
and has been extensively studied in the past years. So far, increased serum concentration of PAPP-A has been described in lung and ovarian cancer and even more, overexpression of PAPP-A has been shown to promote cancer growth and increase cancer aggressiveness in breast and ovarian cancer (6-9).

The role of PAPP-A in RCC remains unclear. The present study aimed to assess PAPP-A serum concentration in subjects suffering from ccRCC and to evaluate its significance in diagnosis, follow-up and assessment of prognosis, which has not been evaluated yet.

\section{Materials and Methods}

Characteristics of study population. In our study we enrolled 121 patients ( 78 men, 43 women, mean age $63.4 \pm 10.52$ years) that were subjected to radical or partial nephrectomy due to ccRCC from July 2011 to August 2015. Negative surgical margins on histopathological specimens of resected tumours were described in all individuals. ccRCC patients were classified into three subgroups: subjects with localized ccRCC without relapse (lccRCC, $n=80$ ), subjects with localized ccRCC with later relapse ( $\mathrm{rccRCC}, \mathrm{n}=26$ ) and subjects with primary metastatic cancer (mccRCC, $n=15$ ). Staging was performed according to the 2009 TNM classification system and Fuhrman classification was used to define the nuclear grade. Surveillance following surgical treatment was performed according to the EAU Guidelines for Renal Cell Carcinoma (10). Median follow-up was 4.6 years. The parameters of the subjects with ccRCC are shown in Table I.

PAPP-A serum concentration was assessed in all individuals preoperatively and in lccRCC ( $\mathrm{n}=23$ patients) and rccRCC $(\mathrm{n}=14$ patients) subgroups 3 weeks and 3 months postoperatively.

The control group consisted of 69 healthy subjects (35 men, 34 women, mean age $58.13 \pm 4.7$ years), who underwent basic urooncological screening including ultrasound, urine cytology and measurement of PSA levels in men. None of them had a history of any oncological disease.

The present study was performed in adherence to the principles stated in the Helsinki Declaration and approved by the institutional review board and ethics committee. Prior to entering the study, all participants gave their informed consent.

PAPP-A serum concentration was assessed by TRACE (Time Resolved Amplified Cryptate Emission) using standard kits and Kryptor analyzer (Brahms GmbH, Thermo Fisher Scientific, Henningsdorf, Germany). Results are expressed in mIU/l. One IU/l is equivalent to $4500 \mathrm{ng} / \mathrm{ml}$ (11).

Statistical analysis. All data are expressed as the mean \pm standard deviation (SD) for continuous variables and percentages for categorical variables. For continuous variables, the difference between two groups was analysed by the Mann-Whitney $U$-test or one-way ANOVA test, as appropriate. For the analysis of continuous variables over time, the repeated measures ANOVA test was used. Survival analysis was performed using the Kaplan-Meier method. To compare survival between patient groups or subgroups the logrank test was applied. Univariate Cox proportional hazards regression analyses were used to evaluate PAPP-A as a potential predictor of overall (OS) and cancer specific survival (CSS). At $p<0.05$ results were considered statistically significant. All
Table I. Clinical parameters of ccRCC cases

\begin{tabular}{lc}
\hline Number of patients (men/women) & $121(78 / 43)$ \\
Age (years) & $63.4 \pm 10.52$ \\
Stage & $78(64.4 \%)$ \\
I & $4(3.3 \%)$ \\
II & $24(19.8 \%)$ \\
III & $15(12.4 \%)$ \\
IV & \\
Grade & $36(29.8 \%)$ \\
1 & $59(48.8 \%)$ \\
2 & $18(14.9 \%)$ \\
3 & $8(6.6 \%)$ \\
4 &
\end{tabular}

Table II. PAPP-A serum concentrations

\begin{tabular}{lcccc}
\hline $\begin{array}{l}\text { PAPP-A serum } \\
\text { concentration } \\
(\mathrm{mIU} / \mathrm{l})\end{array}$ & \multicolumn{3}{c}{ RCC patients } & Controls \\
\cline { 2 - 5 } & & $8.74 \pm 3.5$ & $8.24 \pm 2.3$ \\
\hline & lccRCC & rccRCC & mccRCC & \\
\hline Preoperative & $8.76 \pm 3.7$ & $8.72 \pm 3.1$ & $8.7 \pm 3.4$ & \\
3 weeks after surgery & $9.08 \pm 3.5$ & $8.27 \pm 3.2$ & & \\
3 months after surgery & $9.39 \pm 3.8$ & $9.33 \pm 3.1$ & & \\
\hline
\end{tabular}

Results are not statistically significant.

statistical analyses were performed using MedCalc (version 13, Ostend, Belgium).

\section{Results}

Our results did not show any statistically significant difference in PAPP-A serum concentration between subjects with ccRCC $(8.74 \pm 3.5 \mathrm{mIU} / \mathrm{l})$ and control group $(8.24 \pm 2.3 \mathrm{mIU} / \mathrm{l}), p=0.24$. In addition, no statistically significant difference among lccRCC $(8.76 \pm 3.7 \mathrm{mIU} / \mathrm{l}), \operatorname{rccRCC}(8.72 \pm 3.1 \mathrm{mIU} / \mathrm{l})$ and mccRCC $(8.7 \pm 3.4 \mathrm{mIU} / \mathrm{l})$ subgroups was found $(p=0.99)$. Furthermore, no statistically significant difference in PAPP-A serum concentration was observed even after subdivision of subjects based on tumour stage and Fuhrman's grade $(p=0.76$, $p=0.61$ ). The dynamics of PAPP-A concentrations at 3 weeks and 3 months postoperatively did not reveal any significant difference in lccRCC $(9.08 \pm 3.5$ vs $9.39 \pm 3.8 \mathrm{mIU} / 1, p=1.00)$ or rccRCC $(8.27 \pm 3.2$ vs. $9.33 \pm 3.1 \mathrm{mIU} / 1, p=0.43)$ subgroups. PAPP-A serum concentrations are depicted in Table II.

The median value of PAPP-A serum concentration was used in the survival analysis. Preoperatively, the median was $8.2 \mathrm{mIU} / 1$ and 3 months after the surgery was $9.2 \mathrm{mIU} / 1$. Preoperative and 3 months after surgery PAPP-A serum concentration was not a prognostic factor for CSS or OS (Table III). 
Table III. Cancer-specific and overall survival in patients with localized ccRCC.

\begin{tabular}{|c|c|c|c|c|c|}
\hline \multicolumn{6}{|c|}{ Cancer-specific survival in patients with localized ccRCC } \\
\hline & $\begin{array}{l}\text { Median PAPP-A serum } \\
\text { concentration (mIU/l) }\end{array}$ & $\begin{array}{l}\text { Number of } \\
\text { patients }\end{array}$ & Relapse & $\mathrm{HR}(\mathrm{CI})$ & $p$-Value \\
\hline \multirow[t]{2}{*}{ Preoperative } & $<8.2$ & 53 & $14(26.4 \%)$ & & \\
\hline & $\geq 8.2$ & 53 & $12(22.2 \%)$ & $1.08(0.5-2.35)$ & 0.84 \\
\hline \multirow[t]{4}{*}{3 months after surgery } & $<9.2$ & 18 & $6(33.3 \%)$ & & \\
\hline & $\geq 9.2$ & 19 & $8(42.1 \%)$ & $0.47(0.16-1.37)$ & 0.14 \\
\hline & \multicolumn{5}{|c|}{ Overall survival in patients with localized ccRCC } \\
\hline & $\begin{array}{l}\text { Median PAPP-A serum } \\
\text { concentration (mIU/l) }\end{array}$ & $\begin{array}{l}\text { Number of } \\
\text { patients }\end{array}$ & Exitus & $\mathrm{HR}(\mathrm{CI})$ & $p$-Value \\
\hline \multirow[t]{2}{*}{ Preoperative } & $<8.2$ & 53 & $14(26.4 \%)$ & & \\
\hline & $\geq 8.2$ & 53 & $8(14.81 \%)$ & $1.85(0.8-4.29)$ & 0.15 \\
\hline \multirow[t]{2}{*}{3 months after surgery } & $<9.2$ & 18 & $5(26.3 \%)$ & & \\
\hline & $\geq 9.2$ & 19 & $7(38.9 \%)$ & $0.59(0.19-1.87)$ & 0.38 \\
\hline
\end{tabular}

HR: Hazard ratio; CI: confidence interval. Results are not statistically significant.

\section{Discussion}

In this study, for the first time, the significance of PAPP-A serum concentration in diagnosis and follow-up of ccRCC was evaluated.

PAPP-A, a well-known protease, modulates cell growth through increasing local availability of IGF-1 for receptor binding and activation. IGF-1R stimulation has been proven to initiate malignant transformation promoting cell proliferation, dedifferentiation and inhibiting apoptosis (1214). A range of studies has demonstrated an association between elevated circulating levels of IGF-1 or overexpression of IGF-1R and the risk of developing various tumours including breast, prostate and ovarian cancer (1517). Therefore, several compounds targeting IGF axis have been tested for cancer therapy (18). Regarding kidney carcinoma multiple publications have confirmed the role of IGF-1 and IGF-1R in the development of $\operatorname{RCC}(19,20)$. Parker et al. (21) have demonstrated that expression of IGF$1 \mathrm{R}$ may have a negative prognostic role in patients with ccRCC. Additionally, IGF-1R positivity has been shown to correlate with tumour grade and poorer prognosis (22). Interestingly, ccRCC cells with high expression of IGF-1R show higher resistance to chemotherapeutic agents compared to cells with low receptor expression (23).

The role of the proteolytic function of PAPP-A has been implicated in the growth of various cancers. Elevated levels of circulating PAPP-A have been described in patients with lung cancer and even more, the proteolytic activity of PAPPA was shown to accelerate growth of lung cancer in vivo (6,
24). Mansfield et al. (8) have showed a higher PAPP-A expression in human breast cancer cells, predominantly in its aggressive forms. In addition, several publications have shown that cancer growth and metastases can be prevented by modulating PAPP-A proteolytic activity. Higher expression of proteolytically active PAPP-A molecules in an ovarian cancer cell line has been found to accelerate cancer growth and has also been correlated with cancer aggressiveness in vivo (9). Mikkelsen et al. (25) have first demonstrated that monoclonal antibodies targeting PAPP-A (mAb-PA) efficiently inhibit lung cancer tumour growth (25). Furthermore, PAPP-A has been shown to be overexpressed in human ovarian tumours and treatment of mice models with mAb-PA caused a reduction in tumour growth and ascites burden (26). Therefore, assessment of PAPP-A levels in serum or ascites might be used as a biomarker to identify patients that will respond to anti-PAPPA and anti-IGF, respectively $(26,27)$. Conversely, PAPP-A knock-out mice have a significant delay in the occurrence of neoplasia (28). PAPP-A has also been identified as a migration-promoting gene in breast cancer, malignant pleural mesothelioma and malignant melanoma $(9,29,30)$.

Still, the role of PAPP-A in RCC remains unclear. Since PAPP-A indirectly contributes to the availability and activity of IGF-1, which affects RCC, PAPP-A serum concentration in subjects suffering from ccRCC was evaluated.

However, our results did not meet our expectations. No significant difference was found in PAPP-A serum concentration between subjects with $\mathrm{ccRCC}$ and the control group. Also, the difference in PAPP-A serum concentration after 
subdivision of ccRCC subjects (lccRCC, rccRCC and mccRCC) did not reach statistical significance. In addition, no statistically significant difference in PAPP-A serum concentration was found even after subdivision of subjects based on tumour stage and Fuhrman's grade. The dynamics of PAPP-A postoperative concentrations didn't reveal any significance and no impact on cancer related or overall survival was observed.

Based on the current results, PAPP-A serum concentration does not seem to be a useful biomarker for diagnosis, followup or prediction of prognosis in subjects suffering from ccRCC. Therefore, further research must be done to identify a suitable biomarker for ccRCC. An abundance of potential biomarkers can be found in the literature, yet none has been introduced into routine practice. Until now, no suitable biomarker has been found for the early diagnosis and follow-up of RCC that would have a potential of commercial development and extensive use; this remains the task of further studies.

In conclusion, the significance of PAPP-A serum concentration was evaluated in patients with ccRCC. Although, the role of PAPP-A in carcinogenesis of various tumours has been examined, to the best of our knowledge, our current work assesses for the first time the association between PAPP-A serum concentration and ccRCC. Although PAPP-A appears to be a promising marker for many tumours, our results did not show any significance of PAPP-A serum concentration in subjects with ccRCC in comparison to the control group. In addition, the dynamics of postoperative PAPP-A serum concentration showed no statistical significance. Therefore, PAPP-A does not seem to be a useful biomarker for diagnosis, follow-up and prediction of prognosis in subjects suffering from ccRCC.

\section{Conflicts of Interest}

No potential conflicts of interest with respect to the research, authorship and publication of this article exist.

\section{Authors' Contributions}

Marcela Cechova, MD has contributed with conceptualization, data curation, formal analysis, project administration, writing - original draft. Matus Chocholaty, $\mathrm{MD}, \mathrm{PhD}$ has contributed with conceptualization, data curation, formal and statistical analysis, project administration, validation and writing - review and editing. Prof. Tomas Zima, MD, PhD has contributed with supervision of the laboratory part of the study, writing - review and editing. Prof. Marek Babjuk, MD, PhD has contributed with supervision of the clinical part of the study, writing - review and editing. Prof. Marta Kalousova, $\mathrm{MD}, \mathrm{PhD}$ has contributed with conceptualization, methodology, data analysis, supervision, validation and writing - review and editing.

\section{Acknowledgements}

Results of this study were presented at EAU 17th Central European Meeting in Plzeň, Czech Republic, 2017. Abstract entitled
"Determination of serum level of PAPP-A in patients with clear cell renal cell carcinom" is available at Eur Urol Suppl 16: e2842, 2017. This study was supported by research projects MH CZ - DRO VFN 64165 and Progres Q25. The Authors are thankful to Mrs. Dita Hudcová from the Institute of Medical Biochemistry and Laboratory Diagnostics, Prague, Czech Republic for technical assistance in the study.

\section{References}

1 Capitanio U, Bensalah K, Bex A, Boorjian SA, Bray F, Coleman J, Gore JL, Sun M, Wood C and Russo P: Epidemiology of Renal Cell Carcinoma. Eur Urol 75: 74-84, 2019. PMID: 30243799. DOI: 10.1016/j.eururo.2018.08.036

2 Siegel RL, Miller KD and Jemal A: Cancer statistics, 2018. CA Cancer J Clin 68: 7-30, 2018. PMID: 29313949. DOI: 10.3322/ caac. 21442

3 Gupta K, Miller JD, Li JZ, Russell MW and Charbonneau C: Epidemiologic and socioeconomic burden of metastatic renal cell carcinoma (mRCC): a literature review. Cancer Treat Rev 34: 193-205, 2008. PMID: 18313224. DOI: 10.1016/j.ctrv.2007. 12.001

4 Athar U and Gentile TC: Treatment options for metastatic renal cell carcinoma: a review. Can J Urol 15: 3954-3966, 2008. PMID: 18405442.

5 Conover CA: Key questions and answers about pregnancyassociated plasma protein-A. Trends Endocrinol Metab 23: 242249, 2012. PMID: 22463950. DOI: 10.1016/j.tem.2012.02.008

6 Bulut I, Coskun A, Ciftci A, Cetinkaya E, Altiay G, Caglar T and Gulcan E: Relationship between pregnancy-associated plasma protein-A and lung cancer. Am J Med Sci 337: 241-244, 2009. PMID: 19365167. DOI: 10.1097/MAJ.0b013e31818967a3

7 Alexiadis M, Mamers P, Chu S and Fuller PJ: Insulin-like growth factor, insulin-like growth factor-binding protein-4, and pregnancy-associated plasma protein-A gene expression in human granulosa cell tumors. Int J Gynecol Cancer 16: 1973-1979, 2006. PMID: 17177834. DOI: 10.1111/j.1525-1438.2006. 00724.x

8 Mansfield AS, Visscher DW, Hart SN, Wang C, Goetz MP, Oxvig $\mathrm{C}$ and Conover CA: Pregnancy-associated plasma proteinA expression in human breast cancer. Growth Horm IGF Res 24: 264-267, 2014. PMID: 25468445. DOI: 10.1016/j.ghir.2014. 10.007

9 Boldt $\mathrm{HB}$ and Conover CA: Overexpression of pregnancyassociated plasma protein-A in ovarian cancer cells promotes tumor growth in vivo. Endocrinology 152: 1470-1478, 2011. PMID: 21303951. DOI: 10.1210/en.2010-1095

10 Ljungberg B, Bensalah K, Canfield S, Dabestani S, Hofmann F, Hora M, Kuczyk MA, Lam T, Marconi L, Merseburger AS, Mulders P, Powles T, Staehler M, Volpe A and Bex A: EAU guidelines on renal cell carcinoma: 2014 update. Eur Urol 67: 913924, 2015. PMID: 25616710. DOI: 10.1016/j.eururo.2015. 01.005

11 Kalousová M, Dusilová-Sulková S, Kuběna AA, Zakiyanov O, Levová K, Bocková M, Gedeonová E, Song XC, Ermini ML, Špringer T, Homola J, Tesař V and Zima T: Pregnancyassociated plasma protein A2 in hemodialysis patients: significance for prognosis. Kidney Blood Press Res 42: 509-518, 2017. PMID: 28854436. DOI: 10.1159/000479847

12 Seccareccia $\mathrm{E}$ and Brodt $\mathrm{P}$ : The role of the insulin-like growth factor-I receptor in malignancy: an update. Growth Horm IGF Res 22: 193-199, 2012. PMID: 23098677. DOI: 10.1016/ j.ghir.2012.09.003 
13 Weroha SJ and Haluska P: The insulin-like growth factor system in cancer. Endocrinol Metab Clin North Am 41: 335-350, 2012. PMID: 22682634. DOI: 10.1016/j.ecl.2012.04.014

14 Samani AA, Yakar S, LeRoith D and Brodt P: The role of the IGF system in cancer growth and metastasis: overview and recent insights. Endocr Rev 28: 20-47, 2007. PMID: 16931767. DOI: 10.1210/er.2006-0001

15 Belfiore A and Frasca F: IGF and insulin receptor signaling in breast cancer. J Mammary Gland Biol Neoplasia 13: 381-406, 2008. PMID: 19016312. DOI: 10.1007/s10911-008-9099-Z

16 Roddam AW, Allen NE, Appleby P, Key TJ, Ferrucci L, Carter HB, Metter EJ, Chen C, Weiss NS, Fitzpatrick A, Hsing AW, Lacey JV Jr., Helzlsouer K, Rinaldi S, Riboli E, Kaaks R, Janssen JA, Wildhagen MF, Schröder FH, Platz EA, Pollak M, Giovannucci E, Schaefer C, Quesenberry CP Jr, Vogelman JH, Severi G, English DR, Giles GG, Stattin P, Hallmans G, Johansson M, Chan JM, Gann P, Oliver SE, Holly JM, Donovan J, Meyer F, Bairati I and Galan P: Insulin-like growth factors, their binding proteins, and prostate cancer risk: analysis of individual patient data from 12 prospective studies. Ann Intern Med 149: 461-471, 2008. PMID: 18838726.

17 Endogenous Hormones and Breast Cancer Collaborative Group, Key TJ, Appleby PN, Reeves GK and Roddam AW: Insulin-like growth factor 1 (IGF1), IGF binding protein 3 (IGFBP3), and breast cancer risk: pooledindividual data analysis of 17 prospective studies. Lancet Oncol 11: 530-542, 2010. PMID: 20472501. DOI: $10.1016 / \mathrm{S} 1470-2045(10) 70095-4$

18 Pollak M: The insulin and insulin-like growth factor receptor family in neoplasia: an update. Nat Rev Cancer 12: 159-169, 2012. PMID: 22337149. DOI: $10.1038 / \mathrm{nrc} 3215$

19 Tracz AF, Szczylik C, Porta C and Czarnecka AM: Insulin-like growth factor-1 signaling in renal cell carcinoma. BMC Cancer 16: 453, 2016. PMID: 27405474. DOI: 10.1186/s12885-0162437-4

20 Tao Y, Pinzi V, Bourhis $\mathrm{J}$ and Deutsch E: Mechanisms of disease: signaling of the insulin-like growth factor 1 receptor pathway - therapeutic perspectives in cancer. Nat Clin Pract Oncol 4: 591-602, 2010. PMID: 17898809. DOI: 10.1038/ ncponc0934

21 Parker AS, Cheville JC, Janney CA and Cerhan JR: High expression levels of insulin-like growth factor-I receptor predict poor survival among women with clear-cell renal cell carcinomas. Hum Pathol 33: 801-805, 2002. PMID: 12203212.

22 Ahmad N, Keehn CA and Coppola D: The expression of insulinlike growth factor-I receptor correlates with Fuhrman grading of renal cell carcinomas. Hum Pathol 35: 1132-1136, 2004. PMID: 15343516 .
23 Yuen JS, Akkaya E, Wang Y, Takiguchi M, Peak S, Sullivan M, Protheroe AS and Macaulay VM: Validation of the type 1 insulin-like growth factor receptor as a therapeutic target in renal cancer. Mol Cancer Ther 8: 1448-1459, 2009. PMID: 19509240. DOI: 10.1158/1535-7163.MCT-09-0101

24 Pan H, Hanada S, Zhao J, Mao L and Ma MZ: Protein secretion is required for pregnancy-associated plasma protein-A to promote lung cancergrowth in vivo. PLoS One 7: e48799, 2012. PMID: 23152806. DOI: 10.1371/journal.pone.0048799

25 Mikkelsen JH, Resch ZT, Kalra B, Savjani G, Kumar A, Conover CA and Oxvig C: Indirect targeting of IGF receptor signaling in vivo by substrate-selective inhibition of PAPP-A proteolytic activity. Oncotarget 5: 1014-1025, 2014. PMID: 24572990. DOI: 10.18632 /oncotarget.1629

26 Becker MA, Haluska P Jr, Bale LK, Oxvig C and Conover CA: A novel neutralizing antibody targeting pregnancy-associated plasma protein-a inhibits ovarian cancer growth and ascites accumulation in patient mouse tumorgrafts. Mol Cancer Ther 14: 973-981, 2015. PMID: 25695953. DOI: 10.1158/15357163.MCT-14-0880

27 Thomsen J, Hjortebjerg R, Espelund U, Ørtoft G, Vestergaard P, Magnusson NE, Conover CA, Tramm T, Hager H, Høgdall C, Høgdall E, Oxvig C and Frystyk J: PAPP-A proteolytic activity enhances IGF bioactivity in ascites from women with ovarian carcinoma. Oncotarget 6: 32266-32278, 2015. PMID: 26336825. DOI: $10.18632 /$ oncotarget.5010

28 Conover CA, Bale LK, Mader JR, Mason MA and Keenan KP: Longevity and age-related pathology of mice deficient in pregnancy-associated plasma protein-A. J Gerontol A Biol Sci Med Sci 65: 590-599, 2010. PMID: 20351075. DOI: 10.1093/ gerona/glq032

29 Huang J, Tabata S, Kakiuchi S, The Van T, Goto H, Hanibuchi M and Nishioka Y: Identification of pregnancy-associated plasma protein $\mathrm{A}$ as a migration-promoting gene in malignant pleural mesothelioma cells: a potential therapeutic target. Oncotarget 4: 1172-1184, 2013. PMID: 23896451. DOI: 10.18632/oncotarget.1126

30 Prithviraj P, Anaka M, McKeown SJ, Permezel M, Walkiewicz M, Cebon J, Behren A and Jayachandran A: Pregnancy associated plasma protein-A links pregnancy and melanoma progression by promoting cellular migration and invasion. Oncotarget 6: 15953-15965, 2015. PMID: 25940796. DOI: 10.18632 /oncotarget. 3643
Received May 8, 2019

Revised May 24, 2019

Accepted May 24, 2019 